\title{
Koncepcje Europy Środkowej w Międzymorzu Ziemowita Szczerka
}

\section{Notions of Central Europe in Ziemowit Szczerek's Międzymorze}

\begin{abstract}
The author analyses the image of contemporary Central Europe depicted by Ziemowit Szczerek as an area of continuous interplay between the centre and the periphery. Dissolution, chaos, and mythomania not only seem to indicate the nature of national communities, but also appear to be the reason behind the impossibility of realizing the idea of unification. The questions about the status of Szczerek's statements, which balance between analytical diagnosis and literary narrative based on constructs of the imagination, are also vital for these considerations.
\end{abstract}

Keywords: Ziemowit Szczerek, Central Europe, myth, Intermarium

Streszczenie: Autorka analizuje obraz współczesnej Europy Środkowej ukazywanej przez Ziemowita Szczerka jako teren nieustających gier relacji centrum i peryferii. Rozpad, chaos i mitomania jawią się nie tylko jako wyznaczniki charakteru narodowych wspólnot, ale także jako przyczyny niemożności realizacji idei zjednoczenia. Istotne dla tych rozważań są jednak także pytania o status Szczerkowych konstatacji balansujących między analityczną diagnozą a narracją literacką opartą na deklaracji wyobrażenia.

Słowa kluczowe: Ziemowit Szczerek, Europa Środkowa, mit, Międzymorze

Co łączy „międzymorze” i „śródziemie”? Analizując Międzymorze, poruszać się będziemy także w przestrzeni literatury, nie jedynie publicystyki czy polityki, choć będą one dla omawianych kwestii ważne. Jedną z konsekwentnie ujawnianych fascynacji Szczerka jest literatura fantasy, w tym niewątpliwie świat Śródziemia wykreowany przez J.R.R. Tolkiena. Tytuł omawianej tu prozy nie bez powodu - jak sądzę - wykazuje podobieństwo do nazwy tej mitologicznej krainy. 'Międzymorze' to nie tylko wyraz nieco podobny pod względem słowotwórczym, ale przede wszystkim wywołujący podobne skojarzenia: 'międzymorze' oznacza rejon znajdujący się 'pomiędzy morzami', w środku, a idąc dalej: między czymś a czymś, jak przestrzeń 'pomiędzy ziemiami'. Po cóż mi ta 
zawiła etymologia, skoro łatwo wytłumaczyć kluczowy termin, odwołując się do koncepcji politycznej aktualizowanej tuż przed napisaniem książki? Ano po to między innymi, by wskazać również literacki, a nie jedynie polityczny wymiar tego tekstu. Oba te aspekty łączą się bowiem mimo pozoru niefikcjonalnego charakteru narracji ${ }^{1}$.

Zacznijmy jednak od kontekstu, który wydaje się najbardziej oczywisty. Współczesna koncepcja Międzymorza szczególnie popularna stała się w 2015 roku, gdy w Polsce w wyborach zwyciężyła partia Prawo i Sprawiedliwość, czyniąc hasło utworzenia Międzymorza jednym z postulatów swej polityki zagranicznej. Koncepcja ta zakłada potencjalne porozumienie państw Europy Środkowo-Wschodniej, które miałyby przeciwstawiać się z jednej strony Rosji, z drugiej Zachodowi, i nawiązuje do idei sojuszu narodów centrum kontynentu, marginalizowanych i poddawanych ciśnieniu otaczających je potęg. Wpisuje się też w dyskusję o zasadności podziałów Europy postulowanych, definiowanych, ujmowanych z różnych perspektyw i w różnorodnych kategoriach.

Kontekst polityczno-gospodarczy został zasugerowany także przez wprowadzenie jako motta cytatu z rozmowy z Tomaszem Zaryckim, który podkreśla aktualność rozkładu sił w naszej części świata jako dominacji państw takich jak Niemcy czy Austria, silnych ekonomicznie i wyposażonych w „mocny kapitał symboliczny" ${ }^{2}$. Eksponowany jest w ten sposób ów konstytutywny aspekt Międzymorza - usytuowanie między Wschodem, utożsamianym z Rosją, a Zachodem reprezentowanym przez silne państwa, mniej lub bardziej dominujące w danym momencie na obszarze kontynentu.

Dyskutowany w czasie powstawania książki projekt polityczny stanowić mógł jednak jedynie (ważny) impuls do postawienia pytania o to, czym właściwie jest lub mogłoby być Międzymorze, co określałoby jego istotę i łączyło tworzące je państwa. Tytuł sugeruje bowiem - jak wolno przypuszczać - próbę opisu. Geograficzny aspekt koncepcji wskazuje region określany Europą Środkową, Europą Wschodnią lub Europą Środkowo-Wschodniąa ; pojęcia te czasem używane były wymiennie, ale trudno je uznać za zawsze tożsame. Mają one swój bagaż symboliczny i kulturowy. Przede wszystkim już na początku aluzyjnie przywołany zostaje Milan Kundera, autor jednego z fundamentalnych dla pojęcia Europy Środkowej tekstów: Zachód porwany albo tragedia Europy

1 Nie jest to zresztą praktyka nowa w przypadku tego autora. Gry między fikcja a dokumentem w prozie Szczerka w kontekście między innymi gatunku gonzo omawia na przykład E. Żyrek-Horodyska. Por. taż, Od amerykańskiego snu Thompsona po ukraiński Mordor Szczerka. Estetyzacja świata w duchu gonzo, „Konteksty Kultury” 2017, z. 2. Do kwestii pozoru niefikcjonalności powrócę.

2 Na peryferiach, z Tomaszem Zaryckim rozmawia Katarzyna Kotyńska, „Herito” 2015, nr 21. Cyt. za: Z. Szczerek, Międzymorze. Podróże przez prawdziwa i wyobrażona Europę Środkowa, Warszawa-Wołowiec 2017, s. 5. Dalej cytuję z tego wydania, podając stronę w nawiasie.

3 Ewolucję tych pojęć przypomina i omawia w niniejszym zeszycie Michał Masłowski w artykule Tożsamość w Europie Środkowej. 
Środkowej4. Parafrazując tytuł powieści Kundery, narrator Międzymorza mówi o mieszkańcach Berlina jako nieprzyciążonych ,tą nieszczęsną, znaną na wschodzie Europy, nieznośną ciężkością bytu" (s. 10). Aluzji do rozmaitych kontekstów w inicjalnym fragmencie jest zresztą więcej. Jego tytuł Pozdrowienia z końca historii wyraźnie nawiązuje do słynnej tezy Francisa Fukuyamy głoszącej właśnie koniec historii ${ }^{5}$. Niemcy jako kraj w pełni realizujący ideał liberalnej demokracji mogą jawić się też jako emanacja ideału Zachodu. Ironiczny opis życia mieszkańców Berlina określa w punkcie wyjścia sytuację narratora, którą on sam doprecyzowuje następująco:

Ja jednak nie byłem do końca częścią Zachodu. To znaczy trochę byłem, ale moja peryferyjność, moje położenie pomiędzy skazywało mnie na ten trollerski rechot. A moja peryferyjna zachodniość - na wyrzuty sumienia z tego powodu (s. 11).

Zostaje zatem wprost już zarysowana opozycja: mieszkaniec środkowej części kontynentu, świadomy swej peryferyjności, zawieszony pomiędzy identyfikacją z Zachodem a niemożnością tej identyfikacji, skazany na dystans, tożsamość niepewną i płynną konfrontuje ideały i wartości Europy - właściwej i „prawdziwej”, bezprzymiotnikowej - z doświadczeniem własnym, doświadczeniem mieszkańca potencjalnego Międzymorza. Dzieli te światy „tylko”: „rzeka [a więc położenie geograficzne - D.S.] i historia" (s. 10). Niemało dla jednych, na przykład dla Czesława Miłosza, którego Rodzinna Europa musi stanowić tu istotny punkt odniesienia, nie tak wiele dla innych, jak dla Kundery, który swój wywód opierał przecież na przekonaniu o przynależności naszej części Europy do świata Zachodu. Do zasygnalizowanych w początkowym fragmencie kontekstów dodać trzeba koniecznie jednego jeszcze pisarza: Andrzeja Stasiuka, obecnego tu między innymi za pośrednictwem pojęcia peryferyjności, kluczowego dla jego prozy podejmującej wielokrotnie próbę literackiego opisu Europy Środkowej i jej swoistości w opozycji do Zachodu. Wymienione nazwiska nie wyczerpują katalogu koncepcji zawartych w dziełach pisarzy tego regionu, które mniej lub bardziej bezpośrednio zostają przywołane w Międzymorzu. Obecność tych nawiązań pozwala schematycznie zarysować pytania stawiane w domyśle kreślonego wizerunku tej części Europy ${ }^{6}$. Warto od razu dodać, że rejon poddawany przez Szczerka obserwacji jest bardzo rozległy i obejmuje państwa, których zaliczanie do Europy Środkowej można podać w wątpliwość. Sam autor nie precyzuje ani kryteriów, ani listy tych państw, przyjmując jako zasadę 1984 , nr 5 .

M. Kundera, Zachód porwany albo tragedia Europy Środkowej, „Zeszyty Literackie”

5 F. Fukuyama, The End of History and the Last Man, New York 1992. Polskie tłumaczenie części tej książki: F. Fukuyama, Koniec historii, tłum. T. Bieroń, M. Wichrowski, Poznań 1996.

6 Mimo owej rozległości terenu zasadne wydaje się uznanie, iż właściwie Szczerek utożsamia Międzymorze (rozumiane znacznie szerzej niż projekt polityczny) z pojęciem Europy Środkowej, przynajmniej częściowo, dlatego też, komentując tekst, także traktuję je w ten sposób. 
trasy własnej asocjacyjnej wędrówki po terytorium potencjalnego Międzymorza. Tym samym zdaje się potwierdzać dawno już skonstatowany kłopot z wyznaczaniem terytorium środka Europy i skomplikowanym definiowaniem jego charakteru ${ }^{7}$. Wyklejka na wewnętrznych stronach okładki sugerować może, że owo terytorium łączą marzenia o wielkości, bowiem na mapie zaznaczone zostają „Obszary aspiracji skrajnych nacjonalistów”, wskazujące granice Wielkiej Polski, Wielkiej Litwy, Wielkich Czech, Wielkiej Słowenii i tak dalej, przez wszystkie państwa regionu. A zatem wyznacznikiem tego, co wspólne, jawią się tu marzenia o dominacji i własnej odrębności narzucanej innym. Ten paradoks wyraźnie zapowiada charakterystyczny rys obrazu Europy Środkowej powstającego na kartach Międzymorza.

Od początku funkcjonowania terminu, zgodnie zresztą z dosłownym jego znaczeniem, podstawowym kryterium była kwestia położenia - zarówno w geograficznym, jak i symboliczno-kulturowym sensie - pomiędzy Zachodem a Wschodem, dlatego też stosunek Środkowoeuropejczyków do tych punktów odniesienia staje się jednym z pierwszych tematów dociekań Szczerka. Podaje on w wątpliwość poczucie jedności z Zachodem, tak akcentowane między innymi przez Kunderę, przeciwstawiając mu (domyślnie) na przykład wypowiedzi Serbów wierzących, że lekiem na całe zło współczesności są Rosja i opieka Putina. Przy czym dywagacje i diagnozy Szczerka nie zostają konsekwentnie uporządkowane, autor zdaje się sygnalizować, że nie należy oczekiwać spójnego wywodu, katalogu logicznie zestawionych argumentów. Dlatego możliwe jest przywołanie z jednej strony Kundery, którego koncepcja obejmowała Czechy, Polskę i Węgry, a drugiej zestawianie jego tez z charakterystyką państw bałkańskich. Szczerek gromadzi przykłady myślenia charakterystycznego dla bardzo szeroko rozumianej naszej części Europy, cytując na przykład słowa mieszkańców Bałkanów, którzy odrzucają Zachód, tamtejsze zasady życia, wartości i mentalność. Nawet polityczny podział regionu, państwowe byty stworzone i sankcjonowane przez „wyfiokowany i wylizany Zachód” (s. 17) postrzegają oni jako sztuczne. Autor stawia tezę o demonstracyjnym wręcz lekceważeniu zachodniego świata, które objawia się na przykład w przyjmowaniu reguł współżycia społecznego tylko w zewnętrznych formach, przybierających

Już pod koniec XX stulecia, ćwierć wieku temu, Aleksander Fiut w tekście o znamiennym tytule: Być (albo nie być) Środkowoeuropejczykiem rozważał zasadność używania pojęcia Europy Środkowej i przypominał liczne teksty na ten temat oraz stawiane pytanie o jej istnienie (między innymi w równie chyba znanym jak szkic Kundery eseju Timothy'ego Gartona Asha: Czy Europa Środkowa istnieje? [w:] tegoż, Pomimo i wbrew. Eseje o Europie Środkowej, tłum. A. Husarska, Londyn 1990). Uwagi Fiuta stanowią ciekawy kontekst książki Szczerka, ponieważ w Międzymorzu pobrzmiewa echo stawianych tam pytań i wyrażanych wątpliwości, ale o ile Fiut spoglądał w przyszłość Europy Środkowej, a zwłaszcza jej literatury, z ostrożnym optymizmem, o tyle Szczerek kreśli swój obraz pełen sceptycyzmu. Por. A. Fiut, Być (albo nie być) Środkowoeuropejczykiem [w:] tegoż, Być (albo nie być) Środkowoeuropejczykiem, Kraków 1999, s. 7-34. 
tu całkowicie fasadowy charakter. Tak komentuje autor choćby wprowadzanie zachodnich zasad ruchu drogowego, ignorowanych później przez wszystkich:

Jeździło się tak, jak się chodzi w tłumie, i jeśli się uważało, to w zasadzie wszystko było w porządku. Trzeba było tylko odrzucić zachodnie reguły i działać zgodnie z lokalnymi. W pozornym chaosie była metoda i wszystkie wymyślone za Zachodzie światła na skrzyżowaniach tylko przeszkadzały. (...) No ale światła były. Bo na całym świecie są, więc muszą być i tu. Wstyd byłoby nie mieć. Bo bez świateł miasto byłoby barbarzyńskie, a nie cywilizowane. Bo trzeba nosić garnitury, a nie dżalabije i turbany. Choć (...) widziałem starego faceta, któremu udało się połączyć obie rzeczy, Zachód i Wschód: założył na głowę beret i obwiązał go szalikiem dokładnie tak samo, jak dawniej Turcy i mieszkańcy Bałkanów obwiązywali fezy kefijami (s. 22).

Przytaczam dłuższy fragment, ponieważ w tym przykładzie zawarł Szczerek swoją diagnozę stosunku mieszkańca Europy Środkowej do Zachodu, którą zresztą wprost wykłada: „Peryferie odgrywają przed Zachodem teatrzyk” (s. 22) w polityce, obyczajowych ramach, zewnętrznym wizerunku, a pod tą podszewką kryje się całkiem inny świat, w gruncie rzeczy całkowicie od tego udawanego różny. Dominujące według autora jest przeświadczenie, że my (Polacy, Serbowie, Węgrzy...) lepiej wiemy, jak należy urządzić świat, byle tylko nikt nie wtrącał się, niczego nie oczekiwał i nie narzucał (na przykład s. 332). A zatem nie chodzi o prawdziwą tożsamość z Zachodem, a o pragmatyczne stwarzanie pozorów, wykorzystanie sprzyjających okoliczności. Najdobitniej ujawnia się tego rodzaju myślenie w stosunku do demokracji, to ten wątek stanowi jedną ze swoistych klamer kreślonego przez Szczerka obrazu, pisze on ironicznie w umieszczonym na początku fragmencie (Koniec $\left.{ }^{8}\right)$ : „demokracja to świętość, a święty jej ogień nadal płonie na Zachodzie. I przed tym Zachodem cały ten świat peryferyjnych cwaniaków nadal szopkę odgrywa” (s. 26). Jeden z końcowych fragmentów nosi natomiast tytuł: Tylko frajerzy wierza $w$ demokracje (s. 325-329). Diagnoza brzmi zatem: łączność Europy Środkowej z Zachodem przez wspólnotę wartości jest ułudą, pozorem, mrzonką. Tropieniu podobieństw i różnic - a co za tym idzie, tropieniu rdzenia środkowoeuropejskiej tożsamości - poświęca autor znaczną część swoich rozważań, traktując zresztą ten przymus jak rodzaj fatum: „Ach jakież to jednak przekleństwo urodzić się między tym pieprzonym Wschodem a Zachodem i musieć zwracać na takie rzeczy uwagę" (s. 113). Odnieść można zresztą wrażenie, że owo przekleństwo rozciąga się na każdego mieszkańca tej domniemanej, nieistniejącej rzekomo Europy Środkowej. Czy w fatalizmie owym nie należałoby zatem dostrzegać

8 Tytuł znów czytać można jako aluzyjne nawiązanie do koncepcji Fukuyamy, zwłaszcza że w treści rozdzialiku mowa właśnie przewrotnie o iluzji zwycięstwa liberalnej demokracji. 
elementu wspólnego mianownika? Dociekania dotyczące własnej tożsamości jawią się zresztą jako differentia specifica narodów tej części kontynentu?.

Zatem poczucie przynależności Europy Środkowej do Zachodu jest w Międzymorzu kwestionowane. Podobnie podawana w wątpliwość jest jedność Słowiańszczyzny. Nie ma tu mowy o konsekwentnej konfrontacji z jedną, wybraną koncepcją Europy Środkowej. Gdyby bowiem Szczerek zmierzał jedynie do zakwestionowania jej przynależności do Zachodu, wtedy podważanie tez o istnieniu wspólnoty Słowian byłoby z tym sprzeczne. Do kwestii tej przyjdzie jeszcze powrócić.

Autor Międzymorza rozkłada na czynniki pierwsze mit wspólnoty, akcentuje różnice, pyta na przykład:

co ma wspólnego śródziemnomorska słowiańskość Chorwacji, która w zasadzie nałożyła się na dawniejszą śródziemnomorskość romańską i illyryjską, mieszczańska słowiańskość Czech, która jest tak podobna do kultury niemieckiej (...), góralska słowiańskość Słowacji, dzielona z góralskością, powiedzmy, wołoską (...) (s. 102).

Wymienia kolejne narody, dodając atrybuty osadzone w odrębności geograficznej, co podkreśla rozległość obszaru potencjalnego Międzymorza i - w zamierzeniu, jak sądzę - stale demaskuje iluzję. Jedyne wspólne cechy to poczucie niższości, podobne mity założycielskie i początki języka. Drwi Szczerkowy narrator dość bezceremonialnie, pytając, co miałoby być wartością pansłowiańską: „Noszenie lnianych giezeł? Przycinanie włosów pod garnek?” (s. 102). Rozważania o znaczeniu idei czy mitu słowiańskości obejmują Czechów, Serbów, Chorwatów - w każdym z przypadków zaakcentowane zostają związki z innymi kulturami (zbliżenie Czechów do kultury germańskiej, Chorwatów do śródziemnomorskiej itd.), tym samym autor zdaje się mówić, że więcej przemawia za tym, co odróżnia, że to, co miałoby łączyć, należy właściwie do zamierzchłej, na wpół baśniowej przeszłości. Jednocześnie jednak przy innej okazji konstatuje: „I tak to jest z tą słowiańskością. Niby w nią człowiek specjalnie nie wierzy, niby sprowadza do azteckości, która już nie rodzi, sprowadza do roli języka - a jak przychodzi co do czego, to chwyta się jej człowiek i nie może puścić” (s. 141). Słowiańskość jawi się zatem jako idea scalająca, choć - w opinii autora - pozbawiona racjonalnych podstaw.

Paradoksalnie właśnie mimo negowania istnienia cech wspólnych Szczerek wskazuje punkty łączące kraje naszego rejonu Europy. O ile jednak mit środkowoeuropejski eksponował cechy uznawane przez samych jego wyznawców za pozytywne (między innymi różnorodność, harmonijną koegzystencję,

9 Wspomina o tym Michał Masłowski w artykule Tożsamość w Europie Środkowej w tym zeszycie „Kontekstów Kultury”. Problematyczną tożsamość jako wyróżnik literatury środkowoeuropejskiej wskazywał już Aleksander Fiut we wspomnianym tekście: Być (albo nie być) Środkowoeuropejczykiem, dz. cyt., s. 24. 
wielokulturowość), te wymieniane w Międzymorzu tworzą obraz negatywny. To na przykład słabość i nietrwałość państw („w tym naszym wyśnionym Międzymorzu [...] państwo jest za słabe, by odcisnąć na krajobrazie swoją formę" s. 68), niedziałające lub nieskuteczne instytucje, niestabilne struktury społeczne, wtórność i kiczowatość oraz roszczenia wobec sąsiadów („cała Europa Wschodnia jest jednym wielkim zazębieniem się wzajemnych pretensji”, s. 142). Taki zresztą obraz kreślił Szczerek konsekwentnie już w swoich wcześniejszych książkach, zwłaszcza może w Tatuażu z tryzubem - opisywał tam Ukrainę jako państwo, które niejako z trudem wierzy we własne istnienie, musi je zatem stale umacniać i potwierdzać za pomocą słów, gestów, symboli („im mniej państwa i im większa niemożność zapewnienia obywatelom w miarę normalnych warunków funkcjonowania, tym więcej narodowej symboliki jako erzacu normalności” s. $69^{10}$ ). Powraca też autor Tatuażu z tryzubem do tak lubianych określeń, jak postapokalipsa czy poniemiecja (analogicznie do poradziecji w Tatuażu...), co akcentuje egzystencję wtórną i niesamodzielną. Znamiennym przykładem są przymiotniki opisujące funkcjonariuszy państwa. Zwłaszcza w istotnych fragmentach ukazujących pochód uchodźców pogranicznicy są „przerażeni”, policjanci „zestresowani i zeschizowani” (s. 40, 41, 42) - przymiotniki te zostają wielokrotnie powtórzone. To właśnie w konfrontacji z kryzysem uchodźczym państwa Europy Środkowej obnażają swoją słabość, pragną uniknąć konsekwencji identyfikowania się z zachodnioeuropejskimi wartościami solidarności, niepewność własnej tożsamości skutkuje ksenofobią. Co ciekawe, w kontekście tego kryzysu pojawiły się także na nowo dyskusje o istocie tożsamości środkowoeuropejskiej. Problem ten analizują Marta Cobel-Tokarska i Marcin Dębicki:

„środkowoeuropejskość" jest pojęciem szczególnie mocno zakotwiczonym w domenie wartości, ponieważ pojawia się właśnie w momencie ich próby. Postawa Polski i innych krajów — głosy polityków, panika moralna w mediach oraz sondaże postaw mieszkańców — zostają zatem ocenione i skategoryzowane w szerszym kontekście: na ile Europa Środkowa jest jeszcze swoją „lepszą” wersją, mającą ambicje należeć do kręgu cywilizacji zachodniej, a na ile wyrzeka się tych dążeń i sama wyrzuca się poza nawias europejskiej wspólnoty wartości? ${ }^{11}$

10 Szerzej omówiłam to zagadnienie w referacie: „Czasem wydaje mi się, że rozumiem wszystko, czasem, że nic". Obraz Ukrainy w polskiej literaturze najnowszej na wybranych przyktadach (Ziemowit Szczerek, „Przyjdzie Mordor i nas zje”, „Tatuaz z tryzubem”) wygłoszonym podczas XVI Warsztatów Herbertowskich. Publikacja w przygotowaniu.

11 M. Cobel-Tokarska, M. Dębicki, Z powrotem na wschód od Zachodu? O tożsamości Europy Środkowej w obliczu kryzysu uchodźczego 2015 [w:] tychże, Stowo i terytorium. Eseje o Europie Środkowej, http://www.aps.edu.pl/media/1995779/cobel-tokarska_eseje_o_europie_lekki.pdf, dostęp: 15.10.2019. 
Prześledzenie tej dyskusji może być punktem odniesienia dla tworzonego przez Szczerka obrazu. Kilkoma zaledwie kreskami eksponuje on bowiem słabość i niepewność, brak zakorzenienia i przekonania o wartościach, które Europa Środkowa ma na ustach, ale nie w sercu. Także i na tym przykładzie zaobserwować można owo wspomniane już „odgrywanie teatrzyku” na użytek Zachodu.

Definiowanie i redefiniowanie Europy Środkowej odbywa się zresztą na kartach Międzymorza nieustająco. I nie jest to bynajmniej tworzenie jednego spójnego opisu. Realizuje tu bowiem Szczerek zamierzenie, które zostało przyrównane do układania puzzli. Tyle tylko, że powstaje obraz celowo fragmentaryczny i niekonsekwentny. W innym miejscu bowiem czytamy na przykład, że „Europa Środkowa [to - D.S.]: spokój, bezruch, porządność, poczciwość, nienaruszalność formy i obyczaju” (s. 209), co odbiorcę może nieco zaskakiwać, brzmi bowiem jak zaprzeczenie eksponowanych gdzie indziej cech regionu.

Polityczna idea Międzymorza opiera się na założeniu poczucia jedności celów państw mających je tworzyć, jednak i ono w książce Szczerka zostaje zakwestionowane, bowiem choć każde z państw ma względem Zachodu kompleks peryferii, jednocześnie odczuwa wyższość w stosunku do współtowarzyszy w regionie. Znamienny fragment ukazuje to na przykładzie wyobrażeń Czechów o sobie:

Oni, Czesi, tego Wschodu, którego i Polska jest częścią, a który ciągnie się hen po Władywostok, po Mongolię, po prostu się boją. Jest niewygodny, nieprzewidywalny, nieludzki. Brzydki, kurwa, jest. Oni nie są ze wschodu, oni nie są Wschodem (s. 97).

Szczerek komentuje te słowa konstatacją Czeszki mieszkającej w Szwajcarii: „dla Szwajcarów Czechy to nie żaden Zachód, ba, nawet nie Europa Środkowa ale najzwyklejszy, najszarszy Wschód” (s. 98). A zatem idea Międzymorza, oparta w założeniu na fundamencie jedności krajów regionu, budowana jest na mrzonkach, na czymś, co albo jest niezwykle kruche, albo w ogóle nie istnieje ${ }^{12}$.

$\mathrm{W}$ innym miejscu relacje $\mathrm{w}$ obrębie regionu zostają scharakteryzowane słowami: „peryferia gardzą peryferiami” (s. 90). Ponad pożądanym poczuciem solidarności między państwami wznosi się widmo idei wspólnoty etnicznej:

12 Simona Škrabec, rozważając znaczenie pojęcia Europa Środkowa, zauważa, że jest ona: „rezultatem długotrwałej walki z warunkami, które w swej istocie zawsze są niesprzyjające i to właśnie ta nieustanna walka jest czynnikiem zapewniającym jej spójność, choć jest to spójność bardzo krucha. Ledwo zniknie zagrożenie zewnętrzne, znika również jedność, rozpadając się na tożsamości indywidualne”. S. Škrabec, Geografia wyobrażona. Koncepcja Europy Środkowej wXX wieku, tłum. R. Sasor, Kraków 2013, s. 32. Szczerek ten proces, a właściwie jego skutki, pokazuje, między innymi cytując wypowiedzi pełne stereotypów, splątanego poczucia wyższości wobec sąsiadów i kompleksów wobec Zachodu. 
Ach te etniczne sny. Te rządy etniczności. Ta jej nadrzędność. Europa Środkowa, to nieszczęsne Międzymorze, jest miejscem, gdzie etniczna idea najbardziej zwyrodniała i stała się swoją własną karykaturą. Każdy jest centrum świata. Każdy naród, choćby liczył kilka milionów mieszkańców, a historię musiał sobie domalowywać, dokręcać, dosztukowywać. Tak, każdy naród ma prawo do samostanowienia, więc czemu nie skorzystać (s. 139).

Przypomniane zostają liczne sporne kwestie polityczne (jak w przypadku Węgier opłakujących stale konsekwencje traktatu w Trianon), traumy i obsesje narodowe, wszelkie pomysły podszyte nacjonalizmem. Ich przegląd podmywa obraz scalonego Międzymorza, wspólnego celu, jednolitego stanowiska, które mogłoby stać się siłą regionu. Tytułowa idea stopniowo obnażana jest jako mrzonka, kolejny mit tej części świata. Jawią się zatem krainy Międzymorza jako przestrzeń mitów i wyobrażeń o sobie samych, skomplikowany węzeł kompleksów i wybujałych aspiracji ludzi żyjących w słabej, nieszanowanej demokracji, w świecie chaosu i przypadkowości.

Negatywny wydźwięk tego obrazu stale wzmacnia język opisu. Niemal od początku tej opowieści domniemana wspólnota jest deprecjonowana (na przykład „sytuacja utknęła w dramatycznie beznadziejnym środkowoeuropejskim, międzymorskim błocie" [podkr. - D.S.], s. 25). Negatywne epitety i metafory służą zarówno charakterystyce całego regionu, jak i poszczególnych państw. Serbia na przykład ukazana zostaje jako „opustoszała, wyjąca napisami z murów (...), rozwłóczona, rozłożona na popękanym betonie” (s. 107). Przestrzeń sprawia zazwyczaj wrażenie szarej i koślawej, jak w opisie czeskiego pogranicza, które nawet wiosną, porą roku zwyczajowo uznawaną za piękną, objawia się Szczerkowi w postaci wyjątkowo przygnębiającej:

Krzaki i drzewa wyglądały jak potwory bezradnie wyciągające ku niebu setki cienkich, wysuszonych macek. Świat był nagi i Czechy były nagie (...). wyglądały tak, jakby im ktoś wyrządził krzywdę, obnażył, odarł ze skóry i porzucił. (...) Widać wszystkie trupy i szkielety (s. 85-86).

I dalej mnoży autor pejoratywne określenia, wśród których dominują szarość, pustka, bezruch. Tak dalece sugestywne, że gdyby nie znać opisywanych miejsc, można byłoby uwierzyć, że tak naprawdę wygląda świat Europy Środkowej. Co więcej, Szczerek zdaje się zmierzać do zanegowania także cząstkowych, nieco młodszych mitów, na przykład ten czechofilski, ukształtowany pod wpływem książek Mariusza Szczygła. Opisywane przez autora Międzymorza Czechy w niczym nie przypominają owego sympatycznego raju ${ }^{13}$, nawet tradycyjne utopence otrzymują epitet „paskudne”. Jednak przywołany wyżej

13 Obraz taki zresztą niezupełnie został stworzony przez autora Gottlandu, powstał raczej na skutek uproszczenia treści jego reportaży oraz wypowiedzi w wywiadach. 
cytat dowodzi podporządkowania języka opisu zadaniu tworzenia obrazu metaforycznego i symbolicznego. Krajobraz stanowić ma niejako odzwierciedlenie charakteru narodów i państw umieszczonych przez Historię ${ }^{14} \mathrm{w}$ strefie pośredniej między Zachodem a Wschodem - stąd dominacja bezkształtu, brzydoty wynikającej z nieuformowania i wewnętrznej pustki.

Kreślony przez Szczerka obraz to demontaż mitu Środkowej Europy. Mitu zrodzonego także, a może przede wszystkim w literaturze. Do literackości, o której była mowa na początku tego tekstu, chciałabym teraz powrócić. Eseistyczny charakter prozy ${ }^{15}$, kontekst (między innymi liczne wypowiedzi autora dotyczące sytuacji regionu, jego praca naukowa) przemawiają za potraktowaniem Międzymorza jako wypowiedzi niefikcjonalnej. A jednak nie można zignorować podtytułu, który wprowadza znamienne rozróżnienie: Podróże przez prawdziwa i wyobrażona Europe Środkowa. Zasygnalizowana dwoistość ma znaczące konsekwencje. Z jednej strony zostaje wskazany realny kontekst mowa przecież w tekście o geograficznych, historycznych i politycznych konkretach, z drugiej „wyobrażony” aspekt owej podróży wprowadza niepokojącą niejasność, choć jednocześnie nawiązuje do konstatacji dawno już w tej dyskusji poczynionych. To między innymi wspomniany na początku Kundera mówił o wyobrażeniowych granicach Europy Środkowej, które trzeba wyznaczać na nowo w każdej sytuacji historycznej ${ }^{16}$. Można zatem ów epitet rozumieć w ten sposób - jako uwarunkowanie historyczno-polityczne. Można także odnieść go do wyobrażeń mieszkańców tej części Europy o sobie samych i o niej samej. Oznacza to przywołanie koncepcji, idei i mitów definiujących

14 Mogłoby się wydawać, że Historia - celowo używam takiego zapisu - jawi się tu momentami jako osobowa siła, której decyzje determinują losy państw i narodów.

15 Nawiasem mówiąc, jak słusznie zauważa Weronika Parfianowicz-Vertun (por. taż, Europa Środkowa w tekstach i działaniach. Polskie i czeskie dyskusje, Warszawa 2016, s. 32-39), właśnie esej uznać można za gatunek najbardziej charakterystyczny dla tekstów podejmujących temat Europy Środkowej. Szczerek zatem, dokonując takiego a nie innego wyboru formy swoich rozważań, podejmuje niejako tę „tradycję”, ale jednocześnie doprowadza do pewnej skrajności, zacierając granice i celowo dezorientując odbiorcę. Tu można wyjaśnić, że piszę o pozorze niefikcjonalności, ale nie mam tu na myśli wprowadzania fikcyjnych zdarzeń czy postaci, lecz charakter komentarzy, poglądów, kreślonych przez narratora obrazów. W reportażu byłyby one tak sformułowane, aby czytelnik nie miał wątpliwości, że takie, a nie inne są sądy autora. Tymczasem w Międzymorzu te subiektywne odczucia i refleksje są zmienne, czasem sprzeczne. Narrator podkreśla też na przykład stosowanie używek wpływających na percepcję - dla mnie to wyraźny sygnał dla czytelnika, by nie szukał obrazu pewnego i stałego. Nawiasem mówiąc, zdarzają się i fragmenty, w których opis przestrzeni nie jest zgodny z rzeczywistością (na przykład z dworca kolejowego w Czeskim Cieszynie nie można zobaczyć ulicy Zamkowej po polskiej stronie. Por. s. 86). Nie jest to zarzut, ale w połączeniu z innymi wyraźnie widocznymi zabiegami, o których wspomniałam, rodzi w świadomości odbiorcy niepewność co do prezentowanej mu oceny, refleksji itd. To rozchwianie, moim zdaniem celowe, charakterystyczne dla przemian zachodzących w obrębie gatunku, wpływa na końcowe wnioski dotyczące obrazu Europy Środkowej niemożliwego do jednoznacznego określenia.

16 M. Kundera, dz. cyt., s. 23. 
środkowoeuropejskość, ich konfrontację z owym „realnym” obrazem, który to zabieg nazwałam wcześniej demontażem mitu - nie tyle jednej konkretnej wizji czy koncepcji, ile raczej mglistego zbioru wielu różnych idei, uproszczonych, czasem wewnętrznie sprzecznych czy niekonsekwentnych. Ów chaos i niespójność wyraża kompozycja książki. Narracja meandruje, charakterystyki poszczególnych narodów powtarzają się albo wykluczają, ujęte zostają w różnych perspektywach. W pierwszej lekturze sprawiać to może wrażenie warsztatowych niedostatków. Całostki czy rozdzialiki mają różną długość, różny charakter, czasem są bardzo konkretne, precyzyjne, pisane zdyscyplinowanym językiem, a czasem wręcz przeciwnie - przypominają luźne dywagacje, są demonstracyjnie literackie, o fikcjonalnym wręcz charakterze. Łączone bywają wspólnym tematem albo sprawiają wrażenie przypadkowego czy asocjacyjnego następstwa, układają się przecież w mozaikowy obraz, który nie tworzy wyrazistej całości. A jednak powód jest, jak się wydaje, inny - tej spójnej całości nie ma, zdaje się mówić swym autorskim gestem Szczerek. Nie ma jednej Europy Środkowej, którą w różnych postaciach wyobrażają sobie jej narody (wprost przecież nazywa się je „ojczyznami wyobrażonymi” s. $139^{17}$ ). Mityczne Międzymorze - niczym Tolkienowskie Śródziemie - jest tworem fantastycznym. Bliższym bardziej - to kolejny aspekt podtytułu - tym krainom wyobrażanym sobie przez Zachód, który tu właśnie, w pasie „pomiędzy”, sytuował swoje mityczne czy baśniowe Bordurie i Rurytanie, nie bez powodu tak często przywoływane na kartach Szczerkowej książki.

Znamienny jest też brak właściwie w tworzonym w Międzymorzu obrazie Europy Środkowej tego elementu, który często wymieniany był jako czynnik spajający ${ }^{18}$. Nie mówi Szczerek wprost o wspólnym micie wytworzonym przez pisarzy tego regionu. Owszem, pojawiają się intertekstualne nawiązania, ale wspólnota literatury czy szerzej kultury środkowoeuropejskiej nie jest ani potwierdzana, ani kwestionowana.

Literackość Międzymorza rozpatrywać można w innym jeszcze aspekcie. $\mathrm{Na}$ początku czytelnik znajduje przewrotne zastrzeżenie: „To jest książka podróżnicza. To będzie książka o podróżach i wrażeniach. Komu się to nie podoba, niech odłoży ją już teraz" (s. 9). Zamanifestowany w ten sposób subiektywizm spojrzenia na wstępie już tępi ostrze ewentualnych zarzutów braku konsekwencji, niespójności, powtórzeń, przegadania i wielu innych. Mamy bowiem do czynienia z zapisem subiektywnej podróży - ze wszelkimi metaforycznymi czy symbolicznymi konotacjami. Język opisu często jest eksponowany, nie pełni tylko funkcji użytkowej. A zatem „wyobrażona Europa Środkowa” w podtytule oznaczać może także własną wizję autora, niekoniecznie lub niecałkowicie tożsamą

17 I nie jest to chyba jedynie nawiązanie do „wspólnot wyobrażonych” Benedicta Andersona, ponieważ Szczerek akcentuje także wyobrażenie w prostszym sensie - jako marzenie, iluzję.

18 To właśnie Kundera podkreślał przecież znaczenie kultury dla spójności Europy Środkowej i uważał, że „nie jest [ona - D.S.] państwem, lecz kulturą, losem”. Tenże, dz. cyt., s. 23. 
z ową „prawdziwą Europą Środkową” - jeśli ona w ogóle istnieje, zdaje się mówić Szczerek, a może w takim razie jedynie narrator opowieści? Potwierdzeniem tych domniemań mogą być powtarzające się w wielu miejscach stwierdzenia: „wyobrażałam sobie”. Czasem sugestie są jeszcze bardziej dobitne: „tak go sobie wyobrażałem (...). Kto wie, może to takie samo wyobrażenie jak jego wyobrażona Transylwania” (s. 162), „Czasem próbuję wyobrażać sobie inną historię” (s. 165). Ta wyobrażona Europa byłaby odpowiedzią na środkoweuropejski mit: czy jednak nie równie iluzoryczną? Można bowiem odnieść wrażenie, że w Międzymorzu górę nad realnym bierze właśnie wyobrażone, a nakreślony obraz zawiera, owszem, celne diagnozy i obserwacje, równie jednak wiele uproszczeń i subiektywnych wrażeń. Trudno z nimi dyskutować, jeśli zaopatrzone zostały na wstępie we wspomniane już zastrzeżenie. Szczerkowa koncepcja Europy Środkowej polegałaby zatem na stwierdzeniu niemożności jej realnego istnienia, któremu przeciwstawione zostaje istnienie wyobrażone ${ }^{19}$.

\section{Bibliografia}

Ash T.G., Czy Europa Środkowa istnieje? [w:] tegoż, Pomimo i wbrew. Eseje o Europie Środkowej, tłum. A. Husarska, Londyn 1990.

Cobel-Tokarska M., Dębicki M., Z powrotem na wschód od Zachodu? O tożsamości Europy Środkowej w obliczu kryzysu uchodźczego 2015 [w:] tychże, Stowo i terytorium. Eseje o Europie Srodkowej, http://www.aps.edu.pl/media/1995779/cobel-tokarska_eseje_o_europie_lekki.pdf, dostęp: 15.10.2019.

Fiut A., Być (albo nie być) Środkowoeuropejczykiem [w:] tegoż, Być (albo nie być) Srodkowoeuropejczykiem, Kraków 1999.

Fukuyama F., Koniec historii, tłum. T. Bieroń, M. Wichrowski, Poznań 1996.

Kundera M., Zachód porwany albo tragedia Europy Środkowej, „Zeszyty Literackie” 1984 , nr 5.

Na peryferiach, z Tomaszem Zaryckim rozmawia Katarzyna Kotyńska, „Herito” 2015, nr 21.

Parfianowicz-Vertun W., Europa Środkowa w tekstach i dziataniach. Polskie i czeskie dyskusje, Warszawa 2016.

Škrabec S., Geografia wyobrażona. Koncepcja Europy Środkowej w XX wieku, tłum. R. Sosor, Kraków 2013.

Szczerek Z., Międzymorze. Podróże przez prawdziwą i wyobrażoną Europę Środkową, Warszawa-Wołowiec 2017.

Żyrek-Horodyska E., Od amerykańskiego snu Thompsona po ukrainski Mordor Szczerka. Estetyzacja świata w duchu gonzo, „Konteksty Kultury” 2017, z. 2.

19 Nie byłoby to zresztą wcale stanowisko nowe, czego potwierdzenie znaleźć można w wielu przywołanych już przeze mnie tekstach badaczy Europy Środkowej i jej literatury. 